\title{
The Influence of Leadership Style on the Effectiveness of Office Management in
} Integrated Services Business Offices

\author{
Wu Hsing-lee ${ }^{1}$ \\ ${ }^{1}$ Students of Department of Business Administration, National Taipei University, Taiwan \\ Received: March 10, 2021 \\ Revised: April 12, 2021 \\ Accepted: April 29, 2021
}

\begin{abstract}
The aim of this analysis was to ascertain the degree to which the Head of the Integrated Business Services Office's Leadership Style affects the efficacy of the Integrated Business Services Office's management. In data analysis, a descriptive study of one variable was performed to determine the percentage trend of each test variable; second, the commodity moment correlation formula was used to analyze variable relationships; and third, a basic equation model was used to analyze the impact relationship between the independent and dependent variables. The data for this study were processed using a micro statistical program with the assistance of a computer program. The data analysis and interpretation of the study's hypotheses indicate that there is a significant relationship and influence between the variable leadership style of the Integrated Business Services Office's Head and the effectiveness of the Integrated Business Services Office's management, at the 5\% significance level or $\mathrm{P}=0,05$, respectively.
\end{abstract}

Keywords: Leadership Style, Effective Office Management, Employees

\section{Introduction}

Regional growth is an important part of national development through its execution. Regional growth is accomplished in a variety of ways, including regional autonomy and management of national capital, which provide prospects for improving democracy and achieving productive and successful results in government administration, production, and community services. In implementing policy, growth, and community programs, the government must do so in the context of advancing society's wellbeing toward a political society free of coercion, collusion, and nepotism. To accomplish this, citizen involvement, transparency, and responsibility to society are needed. Additionally under the administration, if a government wishes to maintain a well-organized entity, one way to do so is by "enterprising" conduct. Much as any business, if a government wishes to ensure that its task runs efficiently, it must track progress made.

\section{Methods}

This writer's thesis, which employs the technique "descriptive sample," takes a causal methodology, or examines the effect of one variable on other variables. The focus demographic for this sample is the 22 officers at the Integrated Business Service Office in the City center. Since the actual population is known and smaller than 100 individuals, the sample size is calculated by a survey, ensuring that the sample size is equal to the population. The author collects data in this analysis by using a standardized set of questions and a Likert scale to test and determine respondents' responses. Direct observation or selective observation is conducted using the author's observation criteria at the City Business Integrated Service Office, which served as the sample in this study. 


\section{Results and Discussion}

Table 1 . Respondents by sex

\begin{tabular}{|r|l|r|r|}
\hline No. & information & F. & Percentage (\%) \\
\hline 1. & Male & 39 & 81,25 \\
\hline 2. & woman & 9 & 18,75 \\
\hline & sum & 48 & 100,00 \\
\hline
\end{tabular}

Source: Data Of research results after processing, 2021

According to table 1, the plurality of respondents in this survey were male, as shown by the 81.25 percent figure, with the remaining 18.75 percent being female. Additionally, when presented by age group, the study respondents will see the following details in table 2:

Table 2. Respondents by Age

\begin{tabular}{|l|c|r|r|}
\hline No. & information & \multicolumn{1}{|c|}{ F. } & Percentage $(\%)$ \\
\hline 1. & $<20$ years old & 0 & 0,00 \\
\hline 2. & $21-30$ years old & 16 & 33,30 \\
\hline 3. & $31-40$ years old & 23 & 47,91 \\
\hline 4. & $41-50$ years old & 9 & 18,75 \\
\hline 5. & $51-60$ years old & 0 & 0,00 \\
\hline & sum & 48 & 100,00 \\
\hline
\end{tabular}

Source: Data Of research results after processing, 2021

The respondents' ages vary from 21 to 50 years old, as seen in Table 2 . The bulk of respondents $(47.91 \%)$ were between the ages of 31 and 40, while the remaining 33.33 percent were between the ages of 21 and 30 . The remaining $18.75 \%$ of respondents were between the ages of 41 and 50 .

Table 3 shows the data for respondents depending on their job situation. Civil servants, contractors, and freelancers were the three types of workers that took part in this report. It can be defined in more depth as follows:

Table 3. Respondents based on Staffing status

\begin{tabular}{|l|l|r|r|}
\hline No. & information & F. & Percentage (\%) \\
\hline 1. & Civil Servants & 42 & 87,50 \\
\hline 2. & Contract Employee & 6 & 12,50 \\
\hline 3. & $\begin{array}{l}\text { Daily / Freelance } \\
\text { Employees }\end{array}$ & 0 & 0,00 \\
\hline & sum & 48 & 100.00 \\
\hline
\end{tabular}

Source: Research Data after processing, 2021

It can be deduced from table 3 that almost all of the respondents in this survey are civil servants; the data indicates that the Civil Servant category accounts for 81.50 percent of the total. The majority of the respondents, up to 12.50 percent, are contract workers, with none of them having the rank of regular casual employees.

The interpretation of the data collected would be clarified based on the respondents' answers to the study variables after seeing an analytical summary of the research respondents (Mick, 1996; Lensvelt-Mulders et al., 2005; Conrad \& Schober, 2000). First, each study variable would be subjected to a univariate analysis (one variable analysis). The aim of this univariate

Copyright $@$ 2021, Journal of Asian Multicultural Research for Economy and Management Study, Under the license CC BY-SA 4.0 
study is to look at the middle pattern that emerges objectively from the answers of the respondents to the questions in the questionnaire that was distributed to them. Second, a bivariate approach (two-variable analysis) is used to determine the strength of the interaction between independent and dependent variables. The commodity moment mathematical formula is used in this research. The outcomes of these measurements are used to do a thorough study of the relationship's degree, which is then interpreted. The following would describe the Head of the City Public Street Lighting Office's review of one variable for the variable leadership style.

An successful leadership style is described as one in which a leader may persuade subordinates to do work because he wants to do it and believes he has achieved outcomes that are compatible with his personal objectives.

After considering the aforementioned summary, it can be concluded that the success of leadership in an organisation refers to a leader's capacity to control his subordinates in such a way that there is a sense of unity between leaders and those who are led in achieving organizational objectives.

Leadership is one of the reasons required to introduce modern management of government management at the Regional Office (Waugh \& Streib, 2006; Hughes, 2012; Coppola, 2006; McCaffery, 2013; Aucoin, 1986). Internally, government leadership is responsible for cultivating flexible workforce skills, establishing mutually beneficial vertical and horizontal working partnerships, and fostering a passionate working environment, all based on modern management values, in order to spur the ingenuity of each apparatus of municipal government departments. As a result, continued innovation would be ensured.

\section{Leadership Style Head office Office Integrated Business Office City}

In order to get a better understanding of the Head of the Integrated Services style, general leadership models will be examined, including corporate leadership, wise autocratic leadership, and coaching styles will be used. Additionally, a separate review would be performed on each of each of these leadership types. The corporate leadership style would be first discussed in the first case study.

\section{Executive Leadership Style}

This executive leadership style is one that emphasizes inclusion in terms of the corporate circumstances that necessitate it, while still prioritizing participant engagement (subordinates). The respondents were questioned via questionnaire to ascertain the markers of executive leadership style. The respondent's first predictor response is seen below.

Table 4. Respondent's Response to Involvement in The Implementation of Work in accordance with the authority

\begin{tabular}{|l|r|r|}
\hline information & \multicolumn{1}{|c|}{ F. } & Percentage (\%) \\
\hline Totally agreed & 6 & 12,50 \\
\hline agree & 31 & 64,58 \\
\hline Disagree & 11 & 22,92 \\
\hline disagree & 0 & 0,00 \\
\hline Strongly disagree & 0 & 0,00 \\
\hline sum & 48 & 100,00 \\
\hline
\end{tabular}

Source: Research data, 2021 
According to the details in Table IV.4, more than half of respondents, 64.58 percent, reported that they were still interested in a variety of occupations consistent with their roles and authorities. And only a few objected to what the Head of the City Business Integrated Services Office was doing, as shown by the results, which indicates that only 22.92 percent did. In this situation, it may be assumed that the Head of the Integrated Business Services Office's presence of members (subordinates) in different employment is minimal.

In terms of support and inspiration given to subordinates by the Head of the Integrated Business Services Office in order to maintain high productivity for Office workers, the following table 5 summarizes:

Table 5. Respondents' Responses About the lack of Encouragement and Motivation by Superiors

\begin{tabular}{|l|l|r|r|}
\hline No. & \multicolumn{1}{|c|}{ information } & \multicolumn{1}{c|}{ F. } & Percentage (\%) \\
\hline 1. & Totally agreed & 1 & 12,50 \\
\hline 2. & agree & 37 & 77,08 \\
\hline 3 & Disagree & 5 & 10,41 \\
\hline 4. & disagree & 0 & 0,00 \\
\hline 5. & Strongly disagree & 0 & 0,00 \\
\hline & sum & 48 & 100,00 \\
\hline
\end{tabular}

Source: Research data, 2021

According to the study of table IV.5, as many as 77.08 percent of respondents acknowledged or accepted that the Head of the Integrated Business Services Office encouraged and motivated employees, while some respondents stated that leadership did not necessarily include incentives to maximize labor efficiency.

According to the review of the two tables above, the executive leadership style falls into the "healthy" range. This indicates that the Head of the Integrated Business Services Office has integrated, motivated, and encouraged subordinates to perform their duties. The following section would analyze the wise autocratic leadership style used by the Head of the Kantpr Office of Integrated Business Services.

\section{Wise Autocratic Leadership Style}

According to Chapter 1 of the metrics, the univariate study of the wise autocratic leadership style predictor reveals that the traits involve the leader prioritizing costs and still being proactive (initiative) and energetic. For additional information, see the data visualizations in tables 6 and 7 below:

Table 6. Respondents' Responses to the absence of initiatives in the Development of Office Institutions

\begin{tabular}{|l|l|r|r|}
\hline No. & \multicolumn{1}{|c|}{ information } & \multicolumn{1}{c|}{ F. } & Percentage (\%) \\
\hline 1. & Totally agreed & 7 & 14,58 \\
\hline 2. & agree & 32 & 66,66 \\
\hline 3 & Disagree & 9 & 18,75 \\
\hline 4. & disagree & 0 & 0,00 \\
\hline 5. & Strongly disagree & 0 & 0,00 \\
\hline & sum & 48 & 100,00 \\
\hline
\end{tabular}


Source: Research data, 2021

The analyst's interpretation of Table 6 indicates that more than half, or 66.66 percent, of respondents agreed while also consciously acknowledging the existence of initiatives or initiatives taken by leaders and subordinates in the context of developing Office institutions, since these efforts were consciously beneficial to increasing dynamism and However, even though the number is small, about 18.22 percent, it demonstrates that there are already respondents who oppose policies and initiatives due to respondents' propensity to react rigidly (stagnant) to all office legislation, making it impossible to achieve dynamics in the output of office institutions.

From the table above, it seems as if the actions and leadership styles of wise autocrats continue to remain. This is possible because people, whether under strain or not, are often required to make swift choices in order to meet deadlines for enhancing the institution's efficiency.

Table 7. Respondents' Responses to Leadership Attitudes and Styles

\begin{tabular}{|l|l|l|r|}
\hline No & information & F. & Percentage (\%) \\
\hline 1. & Totally agreed & 4 & 8,33 \\
\hline 2. & agree & 30 & 62,5 \\
\hline 3 & Disagree & 13 & 27,08 \\
\hline 4. & disagree & 1 & 2,08 \\
\hline 5. & Strongly disagree & 0 & 0,00 \\
\hline & sum & 48 & 100,00 \\
\hline
\end{tabular}

Source: Research data, 2021

The study of Table 7 above demonstrates that an autocratic leadership model is often disliked by the office community's lower structures. However, if this form of autocrat results in a wise leadership approach toward overseeing and guiding the Institute, this has been very fruitful, to the point that this type of wise autocrat leadership style naturally falls into a pretty decent group, as shown by data indicating that they approve or agree. 62.5 percent for adopting a prudent autocratic leadership style. According to the table above, even if the decision-making process can be centralized on one hand, it cannot be denied that as a characteristic feature of the eastern culture work ethic, which tends to obey the leader, this style of leadership would still garner positive support. Cost considerations in the execution of corporate operations are a sign of a wise autocratic leadership style (Van et al., 2004; Cokins, 2009; Efferin \& Hartono, 2015). According to research, approximately 50\% of respondents indicated that the Head of the Integrated Business Services Office is worried about costs, although roughly $50 \%$ indicated that the Head of the Office is unconcerned about costs. Additional information can be found in the respondent's declaration in Table 8 below:

Table 8. Respondents' Response to the Importance of Costs in Every Work Implementation

\begin{tabular}{|l|l|r|r|}
\hline No. & \multicolumn{1}{|c|}{ information } & \multicolumn{1}{c|}{ F. } & Percentage (\%) \\
\hline 1. & Totally agreed & 6 & 12,50 \\
\hline 2. & agree & 27 & 56,25 \\
\hline 3 & Disagree & 13 & 27,08 \\
\hline 4. & disagree & 2 & 4,16 \\
\hline 5. & Strongly disagree & 0 & 0,00 \\
\hline & sum & 48 & 100,00 \\
\hline
\end{tabular}

Source: Research data, 2021 
On the basis of all examples of the autocratic leadership model, it can be inferred that the Head of the City Business Integrated Services Office is somewhat adept at applying this wise autocratic leadership style. The critical point is that leadership has made developing initiative and a culture of initiative a priority, which ensures that interest from below continues to grow. Another indicator of his wise autocratic style is that the Head of the Integrated Business Services office has put a premium on funding for different operations. Budget coordination is also being addressed in order to maximize program performance and efficacy. The following section will discuss how the Head of the Integrated Business Services Office empowers his colleagues by his leadership style.

\section{Coaching Leadership Style}

The coach's leadership style is characterized by the fact that the leader of the team often works to defend, protect, guide, and care about his subordinates. For the development of an effective coaching partnership trend between leaders and subordinates, it is critical that leaders and subordinates maintain open contact.

To clarify the coach's leadership style, two primary metrics will be used: First, has the Head of the Integrated Business Services Office often communicated well with his subordinates? Second, can the Integrated Business Services Office's head consistently offer enough guidance and assistance to his subordinates? Present patterns may be determined using these two metrics. For additional details, please refer to the summary of the research data below.

Table 9. Respondents' Responses About the Existence of Good Communication between Superiors and Subordinates

\begin{tabular}{|l|l|r|r|}
\hline No. & \multicolumn{1}{|c|}{ information } & \multicolumn{1}{c|}{ F. } & Percentage (\%) \\
\hline 1. & Totally agreed & 7 & 14,58 \\
\hline 2. & agree & 35 & 72,91 \\
\hline 3 & Disagree & 6 & 12,5 \\
\hline 4. & disagree & 0 & 0,00 \\
\hline 5. & Strongly disagree & 0 & 0,00 \\
\hline & sum & 48 & 100,00 \\
\hline
\end{tabular}

Source: Research data, 2021

The contact between leaders and subordinates at the Integrated Business Services office is effective; as shown in Table 9, 72.91 percent of respondents stated that the leadership developed effective communication, and only a few said that the leadership was extremely restrictive in their communication. Additionally, the results in Table 10 below demonstrate whether contact is effective or not based on the quality and weight of the communication conducted.

Table10. Respondents' Responses to Impressions of Communication with The Head office

\begin{tabular}{|r|r|r|r|}
\hline No. & information & F. & Percentage (\%) \\
\hline 1. & Totally agreed & 8 & 16,66 \\
\hline 2. & agree & 33 & 68,75 \\
\hline 3 & Disagree & 7 & 14,58 \\
\hline 4. & disagree & 0 & 0,00 \\
\hline 5. & Strongly disagree & 0 & 0,00 \\
\hline & sum & 48 & 100,00 \\
\hline
\end{tabular}

Source: Data of research results, 2021 
According to the data described in Table 10, respondents indicated that they approved of the weight and quality of their leaders' communications by a margin of 68.75 percent. And just 14.58 percent of respondents said that the quality of their leader's correspondence was meaningless. Additionally, respondents' answers to markers of the coach's leadership style will be defined as follows in terms of help and cooperation.

Tabel 11. Trespondents assume the support of the head office in every job

\begin{tabular}{|l|l|r|r|}
\hline No. & \multicolumn{1}{|c|}{ information } & \multicolumn{1}{c|}{ F. } & Percentage $(\%)$ \\
\hline 1. & Totally agreed & 7 & 14,58 \\
\hline 2. & agree & 31 & 64,58 \\
\hline 3 & Disagree & 9 & 18,75 \\
\hline 4. & disagree & 1 & 2,08 \\
\hline 5. & Strongly disagree & 0 & 0,00 \\
\hline & sum & 48 & 100,00 \\
\hline
\end{tabular}

Source: Data of research results, 2021

According to the data in table 11 above, it seems that the leadership of the Integrated Business Services Office provides very strong guidance, as shown by the data on respondents who approved with more than half or as many as 64.58 percent and comparatively few who disagreed. Additionally, it would be determined if the Head of the Integrated Business Services Office and his subordinates have cooperated so far. To determine this, refer to the details in Table 12 below:

Table 12. Trespondents think about the existence of good cooperation from the head of the office

\begin{tabular}{|l|l|r|r|}
\hline No & \multicolumn{1}{|c|}{ information } & \multicolumn{1}{c|}{ F. } & Percentage (\%) \\
\hline 1. & Totally agreed & 5 & 10,41 \\
\hline 2. & agree & 27 & 56,25 \\
\hline 3 & Disagree & 16 & 33,33 \\
\hline 4. & disagree & 0 & 0,00 \\
\hline 5. & Strongly disagree & 0 & 0,00 \\
\hline & sum & 48 & 100,00 \\
\hline
\end{tabular}

Source: Research data, 2021

Cooperation is critical for an organisation and no one outcome is obtained solely due to the success of one individual or one specific component, but also due to the cooperation and assistance of other components. In this scenario, it means that collaboration is critical to the organization's success. The significance of this relationship is shown in data table 12, which demonstrates that partnership is already properly regarded by the Head of the Integrated Business Service Office. This was demonstrated by the fact that 56.25 percent of respondents believed that the Head of the Integrated Business Services Office had cooperated well so far. However, these results suggest that the leadership's collaboration was not optimally applied. Almost half have not been completed by the leadership.

The overall description of the above metrics indicates that the Head of the Integrated Business Services Office's leadership style, as defined by the coach, has not been completely applied. On average, the current coach's coaching style is adopted at a rate of approximately $60 \%$.

The following section would identify the Head of the Integrated Business Services Office's study of the bureaucratic leadership style. This leadership style places a premium on adhering to the laws of the game and the value of the organization's job structure. 


\section{Bureaucratic Leadership Style}

As previously mentioned, this hierarchical leadership style is more concerned with enforcing organizational laws and systems. The degree to which a leader follows the laws while doing work is a prerequisite for a leader. Consistency in the application of job rules and systems is a requirement that the Head of the City Business Integrated Service Office must fulfill. This is to avoid doubt and uncertainty in the execution of work and responsibility.

Additionally, the respondent's answers would be defined in terms of their familiarity with the leadership's application of regulations and work processes. The following table 13 will display the following data.

Table 13. Qrespondents' assumptions about the compliance of the Head of Office of Integrated Business Services to Regulations

\begin{tabular}{|l|l|r|r|}
\hline No. & information & F. & Percentage (\%) \\
\hline 1. & Totally agreed & 7 & 14,58 \\
\hline 2. & agree & 38 & 79,16 \\
\hline 3 & Disagree & 2 & 4,16 \\
\hline 4. & disagree & 1 & 2,08 \\
\hline 5. & Strongly disagree & 0 & 0,00 \\
\hline & sum & 48 & 100,00 \\
\hline
\end{tabular}

Source: Data of research results, 2021

What is particularly encouraging about the data in Table 13 is the respondent's optimistic attitude toward the Head of the Integrated Business Services Office's compliance with relevant regulations. This is shown by the fact that 92.84 percent of respondents accepted or strongly agreed that the Head of the Office really prioritizes laws in all job execution.

To verify the truthfulness of the Head of the Integrated Business Services Office's compliance with work laws, the following data summary from table 14 is provided:

Table 14. Respondents' Responses to Possible Employment Are Not Based on Conditions

\begin{tabular}{|l|l|r|r|}
\hline No. & \multicolumn{1}{|c|}{ information } & \multicolumn{1}{c|}{ F. } & Percentage (\%) \\
\hline 1. & Totally agreed & 7 & 14,58 \\
\hline 2. & agree & 25 & 52,08 \\
\hline 3 & Disagree & 11 & 22,91 \\
\hline 4. & disagree & 3 & 6,25 \\
\hline 5. & Strongly disagree & 2 & 4,16 \\
\hline & sum & 48 & 100,00 \\
\hline
\end{tabular}

Source: Data of research results, 2021

The statistics in Table 14 seem to contradict the claims in Table 13. The first point is critical because it indicates that the leadership adheres to the guidelines nearly perfectly, while table 14 indicates that more than half (52.08 percent) of respondents believe that the Head of the Integrated Business Services Office occasionally disregards the work rules. The connotations in Table 14 above suggest that the portrayal of a boss, such as the Head of the Integrated Business Services Office, is not positive.

The discrepancy between the two tables above, particularly the Head of the Integrated Business Services Office's disregard for job laws, could be an error or, perhaps, a very emergency circumstance. This is a possibility for all, assuming it is not caused by intentional causes. 
Indeed, compliance with legislation is synonymous with the leadership's attention to the Organizational Work System. The job scheme in question is the exercise of and individual's duties and authorities in compliance with the institutional framework established by regulations. For additional information, see the respondent comment data in Table 15 below:

Table 15. Respondents' Response to The Amount of Attention to The Work System By the Head of Integrated Business Service Office

$\mathrm{N}: 48$

\begin{tabular}{|l|l|r|r|}
\hline No & \multicolumn{1}{|c|}{ information } & F. & Percentage (\%) \\
\hline 1. & Totally agreed & 7 & 14,58 \\
\hline 2. & agree & 33 & 68,75 \\
\hline 3 & Disagree & 7 & 14,58 \\
\hline 4. & disagree & 1 & 2,08 \\
\hline 5. & Strongly disagree & 0 & 0,00 \\
\hline & sum & 48 & 100,00 \\
\hline
\end{tabular}

Source: Data of research results, 2021

The Head of the Integrated Business Services Office pays considerable attention to the job system. This demonstrates how respectful the leadership is to the job structure developed and established by the organisation. In this scenario, the trend of closeness, nepotism, and subjectivity inherent in all job execution becomes an impediment to the work system's implementation. It is critical to advance the job method, when exposure to subjective matters is dwindling. This ensures that the accomplishments of each section and employee become targets to be met throughout the course of their job. The data in Table 15 demonstrates that the job structure has become a priority (focus), as shown by respondents who stated that the Head of the Integrated Business Services Office paid little attention to the work implementation system, with as much as 68.75 percent stating that the Head of the Integrated Business Services Office paid little attention to the work implementation system.

According to the general definition of the leadership style factors, it is clear that no one leadership style dominates. The four leadership types studied from the Head of the City Business Integrated Service Office fall into the "fairly fine" group. For further univariate research, the distribution of employee participation variables in the City Business Integrated Service Office would be examined.

\section{Variable Effectiveness of Office Management OFFICE Integrated Business Services}

The term "effectiveness" refers to the degree to which the City Business Integrated Service Office succeeds in executing the initiative. The establishment of the Integrated Business Services Office as a professional entity that often strives to produce a meaningful outcome in the form of revenue from usage fees. The following overview of the study findings can be found in the operationalization of the Integrated Business Services office's vector management effectiveness.

Table 16. Respondents' Responses to The Results of Evaluation of The Success of The Integrated Business Service Work Program Increased

\begin{tabular}{|l|l|r|r|}
\hline No. & \multicolumn{1}{|c|}{ information } & \multicolumn{1}{c|}{ F. } & Percentage ( \%) \\
\hline 1. & Totally agreed & 7 & 14,58 \\
\hline 2. & agree & 31 & 64,58 \\
\hline 3 & Disagree & 10 & 20,83 \\
\hline 4. & disagree & 0 & 0,00 \\
\hline
\end{tabular}

Copyright $\odot$ 2021, Journal of Asian Multicultural Research for Economy and Management Study, Under the license CC BY-SA 4.0 


\begin{tabular}{|l|l|r|r|}
\hline 5. & Strongly disagree & 0 & 0,00 \\
\hline & sum & 48 & 100,00 \\
\hline
\end{tabular}

Source: Data of research results, 2021

The details in Table 16 above indicate that the evaluation generated positive outcomes. A total of 64.58 respondents indicated that the Integrated Business Services office program's achievement of outcomes increased from time to time. Additional proof of this accomplishment can be found in the details presented in Table 17 below:

Table 17. Respondents' Response to The Achievement of Increased Revenue Levy by Integrated Business Service Office

\begin{tabular}{|l|l|r|r|}
\hline No & \multicolumn{1}{|c|}{ information } & F. & Percentage (\%) \\
\hline 1. & Totally agreed & 11 & 22,91 \\
\hline 2. & agree & 31 & 64,58 \\
\hline 3 & Disagree & 6 & 12,50 \\
\hline 4. & disagree & 0 & 0,00 \\
\hline 5. & Strongly disagree & 0 & 0,00 \\
\hline & sum & 48 & 100,00 \\
\hline
\end{tabular}

Source: Data of research results, 2021

About $80 \%$ of respondents believe or firmly agree that there has been a boost in local income for the Integrated Business Services Office from the levy market so far. The criteria outlined above are ideal for the Integrated Business Services Office to succeed. Since the Integrated Business Service Office's increased sales would have an impact on the Region's growing capacity to achieve expenditure independence.

Additional evidence of the City Business Integrated Service office's potential to contribute to area sales can be seen in the results in Table 18 below:

Table 18. Respondents' Response to the results of the Office of Integrated Business Services for Overall Regional Revenue and Levy

\begin{tabular}{|l|l|r|r|}
\hline No & information & \multicolumn{1}{|c|}{ F. } & Percentage (\%) \\
\hline 1. & Totally agreed & 6 & 12,50 \\
\hline 2. & agree & 36 & 75,00 \\
\hline 3 & Disagree & 6 & 12,50 \\
\hline 4. & disagree & 0 & 0,00 \\
\hline 5. & Strongly disagree & 0 & 0,00 \\
\hline & sum & 48 & 100,00 \\
\hline
\end{tabular}

Source: Data of research results, 2021

According to the data in Table 18, three emaptors or $75 \%$ of respondents reported that the revenue from the Integrated Business Services Office retaliation was still rising. This has a significant impact on employee morale. That when tax targets are met and the municipal budget is in surplus, employers often receive bonuses that promote sustained accomplishment.

How well the Integrated Business Services Office does as a whole can be determined in order to determine if the City Business Integrated Service Office may be classified as a dependable municipal professional entity or not. For additional details, please see the data overview in Table 19 below: 
Table 19. Respondents' Response to the Success of Office Performance of Integrated Business Services Office So Far

\begin{tabular}{|l|l|r|r|}
\hline No. & \multicolumn{1}{|c|}{ information } & \multicolumn{1}{c|}{ F. } & Percentage (\%) \\
\hline 1. & Totally agreed & 19 & 39,58 \\
\hline 2. & agree & 23 & 47,91 \\
\hline 3 & Disagree & 6 & 12,5 \\
\hline 4. & disagree & 0 & 0,00 \\
\hline 5. & Strongly disagree & 0 & 0,00 \\
\hline & sum & 48 & 100,00 \\
\hline
\end{tabular}

Source: Research data, 2021

Almost all respondents, or 87.5 percent, believe that the City Business Integrated Service Office has shown superior efficiency. In this situation, the efficiency of workers in the Integrated Business Services office setting qualifies as good.

Overall, based on the study of this single variable, it can be concluded that the relationship between the variables of the Head of the City Business Integrated Service Office's leadership style and the extent of achieving the efficacy of the Integrated Business Services Office's management is favorable. This indicates that both are equally similar (balanced) in terms of percentage.

Hypothesis research may be used to examine the association between the variable Leadership Style of the Integrated Business Services Office's Head and the efficacy of the Integrated Business Services Office's administration. According to the effects of mathematical measurements conducted on the commodity moment association using a calculator, the value $(\mathrm{rX} 1 \mathrm{Y})$ is 0.519 . The result of this equation indicates that the Employee Participation Variable has a favorable (+) association with the Integrated Business Services Office's Management Effectiveness and is in the low connection band. Additionally, to determine the importance of the corresponding correlation coefficient value, it was compared to the r-table value of the product's moment of critique price at a $5 \%(0.05)$ significance standard with $\mathrm{N}=22$. At a $5 \%$ (0.05) degree of importance, the r-table meaning of the commodity moment is 0.423 . The estimated correlation coefficient of 0.519 is simply greater than the r-table meaning for the commodity moment, or rx1y (0.519)> $\mathrm{r}$ table (0.423). Thus, the correlation coefficient $\mathrm{r}$ is meaningful at the $5 \%$ stage of significance (0.05).

The mathematical research findings are then correlated with the proposed partnership analysis's third hypothesis. The third theory advanced in this report, namely that there is a substantial association between the Head of the Integrated Business Services Office's Leadership Style and the Integrated Business Services Office's management effectiveness, is both acceptable and empirically validated in the sector. Additionally, that can be seen by the degree of variable $\mathrm{X} 1$ 's relation to shifts in variable $\mathrm{Y}$, as explained by the coefficient of determination ( $\mathrm{r} 2$ ). Statistical calculations yielded a coefficient of decision (r2) of 0.269 , or approximately 26.9 percent. This assumes that the X2 component (Employee Participation) accounts for $100 \%$ of the overall benefit of the vector Y (Management Effectiveness of Integrated Business Services Office). While the remaining 69.3 percent were clarified by non-model variables. This suggests that additional variables impair the efficiency of the Integrated Business Services office's administration.

The regression coefficient derived from the independent variable to the dependent variable as a function of the regression study. Additionally, the regression estimation effects may be shown to provide a more precise calculation outcome. The Head of the Integrated Business Services Office's regression coefficient for workforce engagement is 0.502 . This demonstrates that there

Copyright ( $)$ 2021, Journal of Asian Multicultural Research for Economy and Management Study, 
is a direct or beneficial impact. This suggests that the impact of shifts in the Head of the Integrated Business Services Office's leadership style on employee engagement in the Integrated Business Services Office's management is 0.502. The findings of the regression coefficient evaluation indicate that the regression coefficient significance is statistically important. This indicates that the Head of the Integrated Business Services Office's variable leadership style has a sizable impact on staff interest in the Integrated Business Services Office's administration. Thus, the basic regression equation $\mathrm{Y}=0.741+0.502$ (X1) can be used to forecast the level of employee involvement in the management of the Integrated Business Services Office.

The regression coefficient estimate for the workforce engagement measure and the efficacy of the Integrated Business Services Office's management is 0.461 (Flammer et al., 2019). This suggests that staff engagement has a clear and constructive impact on the success of the Integrated Business Services Office's administration. As a result, the correlation coefficient has a large significance. This indicates that workforce engagement has a direct impact on the success of the Integrated Business Services Office's administration. Thus, the effects of the basic regression equation $\mathrm{Y}=1.468+0.461$ (X2) will be used to forecast the magnitude of the success attained in managing the Integrated Business Services Office.

The final study of the regression analysis determines the impact of the predictor of the Head of the Integrated Business Services Office's leadership style on the efficacy of the Integrated Business Services Office's administration. The regression study calculated a regression coefficient of 0.297. This suggests that the Leadership Style of the Integrated Business Services Office's Head has a clear and constructive impact on the Integrated Business Services Office's management effectiveness. As a result, the correlation coefficient has a large significance. This indicates that the Leadership Style of the Integrated Business Services Office's Head has a sizable impact on the Integrated Business Services Office's management effectiveness. Thus, the effects of the basic regression equation $\mathrm{Y}=0.187+0.297$ (X1) will be used to forecast the magnitude of the success gained in managing the Integrated Business Services Office.

\section{Conclusion}

The basic regression equation $\mathrm{Y}=0.187+0.297 \mathrm{X} 1$ demonstrates the impact of the Head of the Integrated Business Services Office's leadership style on the success of the Integrated Business Services Office's administration. The regression coefficient obtained is 0.297, which is positive (+). This condition demonstrates that the leadership style of the Head of the Integrated Business Services Office has a major impact on the success of the Integrated Business Services Office's administration at a stage of 5\%. (0.05).

\section{References}

Aucoin, P. (1986). Organizational change in the machinery of Canadian government: From rational management to brokerage politics. Canadian Journal of Political Science/Revue canadienne de science politique, 3-27.

Cokins, G. (2009). Performance management: Integrating strategy execution, methodologies, risk, and analytics (Vol. 21). John Wiley \& Sons.

Conrad, F. G., \& Schober, M. F. (2000). Clarifying question meaning in a household telephone survey. Public Opinion Quarterly, 64(1), 1-28.

Coppola, D. P. (2006). Introduction to international disaster management. Elsevier.

Efferin, S., \& Hartono, M. S. (2015). Management control and leadership styles in family business. Journal of Accounting \& Organizational Change. 
Flammer, C., Hong, B., \& Minor, D. (2019). Corporate governance and the rise of integrating corporate social responsibility criteria in executive compensation: Effectiveness and implications for firm outcomes. Strategic Management Journal, 40(7), 1097-1122.

Hughes, O. E. (2012). Public management and administration: An introduction. Macmillan International Higher Education.

Lensvelt-Mulders, G. J., Hox, J. J., Van der Heijden, P. G., \& Maas, C. J. (2005). Meta-analysis of randomized response research: Thirty-five years of validation. Sociological Methods \& Research, 33(3), 319-348.

McCaffery, P. (2013). The higher education manager's handbook: effective leadership and management in universities and colleges. Routledge.

Mick, D. G. (1996). Are studies of dark side variables confounded by socially desirable responding? The case of materialism. Journal of consumer research, 23(2), 106-119.

Van Vugt, M., Jepson, S. F., Hart, C. M., \& De Cremer, D. (2004). Autocratic leadership in social dilemmas: A threat to group stability. Journal of experimental social psychology, 40(1), 1-13.

Waugh Jr, W. L., \& Streib, G. (2006). Collaboration and leadership for effective emergency management. Public administration review, 66, 131-140. 